\title{
Correction to: The development of the Norwegian wrasse fishery and the use of wrasses as cleaner fish in the salmon aquaculture industry
}

\author{
Enrique Blanco Gonzalez ${ }^{1,2} \cdot$ Femke de Boer ${ }^{3,4}$
}

Published online: 2 April 2021

(c) The Author(s) 2021

\section{Correction to: Fish Sci (2017) 83:661-670 https://doi.org/10.1007/s12562-017-1110-4}

The article "The development of the Norwegian wrasse fishery and the use of wrasses as cleaner fish in the salmon aquaculture industry", written by Enrique Blanco Gonzalez and Femke de Boer, was originally published Online First without Open Access. After publication in volume 83, issue 5, page $661-670$ the author decided to opt for Open Choice and to make the article an Open Access publication. Therefore, the copyright of the article has been changed to (c) The Author(s) 2021 and the article is forthwith distributed under the terms of the Creative Commons Attribution 4.0 International License (https://creativecommons.org/licenses/ by/4.0/), which permits use, sharing, adaptation, distribution and reproduction in any medium or format, as long as you give appropriate credit to the original author(s) and the source, provide a link to the Creative Commons licence, and indicate if changes were made. The original article has been corrected.

Open Access This article is licensed under a Creative Commons Attribution 4.0 International License, which permits use, sharing, adaptation, distribution and reproduction in any medium or format, as long as you give appropriate credit to the original author(s) and the source, provide a link to the Creative Commons licence, and indicate if changes were made. The images or other third party material in this article are included in the article's Creative Commons licence, unless indicated otherwise in a credit line to the material. If material is not included in the article's Creative Commons licence and your intended use is not permitted by statutory regulation or exceeds the permitted use, you will need to obtain permission directly from the copyright holder. To view a copy of this licence, visit http://creativecommons.org/licenses/by/4.0/.

The original article can be found online at https://doi.org/10.1007/ s12562-017-1110-4.

Enrique Blanco Gonzalez

enrique.blanco@uia.no

Femke de Boer

fbdeboer@hotmail.com

1 Department of Natural Sciences, University of Agder, Postbox 422, 4604 Kristiansand, Norway

2 Center for Coastal Research, University of Agder, 4604 Kristiansand, Norway

3 Institute of Biological and Environmental Sciences, University of Aberdeen, Tillydrone Avenue,

Aberdeen AB24 2TZ, UK

4 Good Fish Foundation, Kerkewijk 46, 3901 EH Veenendaal, The Netherlands 
Publisher's Note Springer Nature remains neutral with regard to jurisdictional claims in published maps and institutional affiliations. 